\title{
The Effect of Emotional Intelligence and Self Effycacy Towards Students Achievement
}

\author{
Muhamad Farhan*, Edward Alfin \\ FMIPA, Universitas Indraprasta PGRI Jakarta. \\ Jln. Raya Tengah No. 80 Kelurahan Gedong Pasar Rebo Jakarta Timur, Jakarta, Indonesia \\ E-mail: muhamadfarhan2011@gmail.com \\ Article received : February 2019, article revised : Agustus 2019, article published: September 2019
}

DOI : $10.25273 /$ jipm.v8i1.4669

\begin{abstract}
This research aims at revealing the effect of emotional intelligence and self-efficacy towards learning achievement of the 8th grade students in SMP Islam Terpadu Ar-Rahman south of Jakarta. This type of research is a survey method. Data instruments are emotional intelligence questionnaires and self-efficacy questionnaires, the mathematics learning achievement data from the daily test scores of students through the description questions. The data analysis technique used is multiple regression analysis. The results of the regression analysis of significance between emotional intelligence on mathematics learning achievement showed the results as much as 0,551 $(0,551>0,05)$, self-efficacy towards mathematics learning achievement as much as $0.333(0.333>$ $0.05)$. The significance of variance analysis was obtained at $0.350(0.350>0.05)$. The results of this data analysis show that emotional intelligence and self-efficacy together no meaningful affect the learning achievement of mathematics. The implication of this study is that students who have high and moderate emotional intelligence and self-efficacy do not have a significant effect on improving learning achievement, thus emotional intelligence and self-efficacy are not the main factors that influence student learning achievement.
\end{abstract}

Keywords: Emotional Intelligence; Self-Efficacy; Learning Achievement

\section{INTRODUCTION}

Mathematics learning as one of the basic sciences that plays an important role in daily life and the progress of various sciences and technologies (Maharani, Nusantara, Rahman, \& Qohar, 2019). Means and infrastructures of learning and a controlled and conducive learning environment are the determining factors in achieving maximum learning achievement. Slameto (2015) classifies these factors as internal and external factors, where internal factors consist of physical factors, psychological factors, and fatigue factors while external factors consist of family, school, and community factors. Examples of these factors are emotional intelligence, critical thinking skills, mathematical communication, self-efficacy, and many other factors.

Based on the results of observations and interviews with teachers in the field of mathematics studies that SMP Islam Terpadu Arrahman Jakarta Selatan students also lack confidence in their abilities, especially in the process of solving mathematical problems. For example, when students present in front of the class, students still lack confidence when delivering results of presentations and answering questions from other students. Students also tend to be shy when asking questions to the teacher. Students lack confidence in the mathematical answers obtained from the problem-solving process, so students tend to close themselves and do not dare to express it; 
this makes the process of solving mathematical problems hampered. The results of the researchers' direct interviews with several students stated that they lacked confidence and were not sure of the answers they got, so they were more likely to give up.

Some important information obtained from mathematics teachers is that SMP Islam Terpadu Arrahman Jakarta Selatan students are on average students who fail to enter selection from public schools and the average student has a lower middle economic background so that in addition to learning activities at school, students also selling, etc. After returning home from school there are students who sell and play around in the community so that the repetition process or reviewing material at home that has been obtained at school is not optimal and is more likely for students not to review at all, this has an impact on low learning achievement. Students know the outside environment very well, but the process of interaction that occurs outside the environment will indirectly have a positive and negative impact on the development of student learning. Emotional intelligence will encourage students to carry out social interactions in the classroom and outside the classroom, and self-efficacy will encourage students to have stability in acting during the learning process.

Emotional intelligence needs to be instilled since childhood as a basic foundation in the lives of students in the future so that students become strong individuals in terms of academic abilities and abilities in social interaction. Emotional intelligence provides space for students to be able to survive in various problem situations, especially mathematical problems. Thus, emotional intelligence provides a significant role in the development of students (students) in the learning process, without the presence of emotional intelligence students will easily give up and do not have the motivation to learn.

Goleman (2015) suggests that intellectual intelligence (IQ) only contributes $20 \%$ to success, while $80 \%$ is contributed by other power factors, one of which is emotional intelligence. Have emotional intelligence High will help students to continue to practice and try when experiencing failure in the problemsolving process. Students will know that the success and failure of a sequence of processes that must be passed in learning interaction.

Daud (2012) define emotional intelligence as the ability to feel, understand, and effectively apply emotional power and sensitivity as a source of human energy, information, connections, and influence. The ability of students to manage emotions will determine how students must behave and act to improve the quality and ability of themselves and students have good management skills of learning time; students will be able to arrange systematically and programmed learning schedules. Thaib (2013) said that emotional intelligence could be expressed as one of the important factors that should be owned by students who have the need to achieve better learning achievement in school and prepare them to face the real world.

Emotional intelligence can spur student motivation to keep trying and not easily give up, able to accept reality, and can solve problems well despite difficulties. The results of research conducted by Febrianti \& Rachmawati (2018) say that emotional intelligence significantly influences learning outcomes. The results of other studies by Salami \& Ogundokun (2009) revealed that emotional intelligence has a significant positive correlation with academic performance.

Emotional intelligence is able to control the condition of students in the learning process 
with the existence of emotional intelligence students have more ability to motivate themselves in learning both in class and outside the classroom, students are ready to face all circumstances including failure in the process of solving mathematical problems, students will be able to survive to manage mental states and controlling emotions so that they can respond correctly to both themselves and others.

The emotional intelligence indicators measured in this study are based on $\mathrm{N}$ urdiansyah (2016), i.e., recognizing selfemotions; managing emotions; motivating yourself; recognizing the emotions of others (empathy); and; fostering relationships. Selfefficacy is a fundamental subjects are taught at all grade levels to all students across the world (Lee, Walkowiak, \& Nietfeld, 2017; Louis \& Mistele, 2012). Mathematics selfefficacy is closely related to mathematics self-concept (Bagaka's, 2011; Bursal, 2010; Huang, Zhang, \& Hudson, 2018). Selfefficacy (self-ability) is also needed in learning activities, confidence in a person about his ability to organize and take action to achieve predetermined goals so that students never feel discouraged by the academic tasks given and keep trying to solve problems during the learning process. Hendriana, Rohaeti, E., \& Sumarmo (2017) said that one's ability is one's belief in his ability to coordinate his skills and abilities to achieve the desired goals in certain domains and circumstances.

Self-efficacy greatly influences his perception, motivation, and actions in various ways, including in his academic abilities. Someone who has high self-efficacy will build more academic abilities, while low selfefficacy will hamper and slow down academic development. The output of education has not been able to run in the balance due to the lack of self-efficacy, which results in low student achievement.

Maltby, Day, \& Macaskill (2010) argued that self-efficacy affects one's motivation to complete tasks, perseverance displayed by someone in working for a particular goal, and the likelihood of that person's success. According to some individuals, maybe a task can be considered easy but, maybe also some others think otherwise. Individuals who have selfefficacy weak will tend to avoid the task given if faced with the task at a higher level of difficulty while individuals who have selfefficacy strong will feel the task as a challenge to be solved.

The results of research conducted by Safaria (2013) mention students with high self-efficacy contribute to higher goals than students with low self-efficacy, students with high self-efficacy believe that they can achieve higher grades on when the test is compared to low self-efficacy. Therefore, self-efficacy provides a very large influence on improving student learning patterns in solving mathematical problems.

How to regulate self-efficacy in achievement Bandura revealed Hamdi \& Abadi (2014) that there are three main ways in which self-confidence operates an important contributor to developing cognitive competencies that govern academic achievement: students' confidence in their success to master different academic subjects, teachers' beliefs in their personal success to support and promote learning in their students, and incorporation of ideas or institutional thinking if students and teachers can successfully achieve significant academic progress.

The perception of self-efficacy is not just a concept of thinking about what actions to take in the future, but one's beliefs about one's abilities also function as a determinant of how individuals behave, manage thinking 


\section{JIPM (Jurnal Ilmiah Pendidikan Matematika), 8(1), September 2019- 40}

Muhamad Farhan, Edward Alfin

abilities, and provide positive emotional reactions to situations that are experienced. Ardyanti \& Harini (2015) said that there is a positive relationship between self-efficacy and mathematics learning achievement, and Salami \& Ogundokun (2009) stated that selfefficacy academics found to be significantly related to student academic performance, emotional intelligence and academic selfefficacy are strong predictors of student academic performance. Safaria (2013) mention that self-efficacy is a far stronger predictor of how effectively a person will perform the task given than their self-esteem or selfesteem. A high level of self-efficacy makes people work hard and survive in the face of setbacks. In a dynamic work context, where continuous learning and improved performance are needed, high self-efficacy helps individuals to react more defensively when they receive negative feedback.

The indicators self-efficacy measured in this study are (1) students' confidence in their abilities; (2) students' confidence in the perception of self-assessment related to selfcontrol; (3) students' confidence in the timeliness of completing their assignments; (4) students' confidence in math tasks that are able to be completed well; (5) Students' confidence in the amount of effort and perseverance to achieve success.

\section{METHODE}

This research use survey method because it does not provide treatment, but only reveals facts that occur naturally and are already underway. This research was conducted at the SMP Islam Terpadu Arrahman Jakarta Selatan in academic years 2018/2019. Populasi dalam penelitian ini adalah seluruh siswa SMP Islam Terpadu Arrahman Jakarta Selatan tahun pelajaran 2018/2019. The sample in this study were all VIII class students of
SMP Islam Terpadu Arrahman Jakarta Selatan amount 69 students which consist 3 classes.

The type of data in this study is quantitative data. Data collection techniques used in this study were tests and questionnaires given once. Data instruments used were emotional intelligence questionnaire and selfefficacy questionnaire each of 30 statements with reference to the Likert scale. The mathematics learning achievement data is taken from the students' daily test scores through the question description.

Data analysis uses the comparison of different groups, or influences between variables, as well as interpreting comparisons between research results and those predicted before research. The statistical data analysis uses the SPSS 16.0 program to conduct descriptive analysis, test assumptions, and hypotheses. The assumption test uses the normality test, collinearity / multicollinearity test, heterocedasticity test, and linearity regression test. Hypothesis testing using the method of correlation analysis and multiple linear regression, this analysis is used to determine the effect of the independent variable with the dependent variable, whether each independent variable has a positive or negative effect.

\section{RESULT AND DISCUSSION}

The analysis used SPSS 16.0 show that the minimum score, the maximum score, mean, standard deviation and varians from each variables. The result of descriptive analysis can be viewed in Table 1 and Table 2. Below:

Table 1. Data of Research

\begin{tabular}{lccc}
\hline & $\begin{array}{c}\text { Emotional } \\
\text { Intelligence }\end{array}$ & $\begin{array}{c}\text { Self } \\
\text { Effycacy }\end{array}$ & $\begin{array}{c}\text { Achieve- } \\
\text { ment }\end{array}$ \\
\hline Minimum score & 66,00 & 58,00 & 0,00 \\
Maximum score & 98,00 & 116,00 & 100,00 \\
Mean & 79,928 & 88,015 & 29,493 \\
SD & 6,088 & 11,849 & 18,907 \\
Variance & 37,068 & 140,397 & 357,560 \\
Total & & 69 & \\
\hline
\end{tabular}


Table 2. Categorize of each variables

\begin{tabular}{lcc}
\hline \multicolumn{1}{c}{ Category } & $\begin{array}{c}\text { Emotional } \\
\text { Intelligence }\end{array}$ & $\begin{array}{c}\text { Self } \\
\text { Effycacy }\end{array}$ \\
\hline Very high & $0 \%$ & $0 \%$ \\
High & $22 \%$ & $14 \%$ \\
Middle & $75 \%$ & $55 \%$ \\
Low & $3 \%$ & $30 \%$ \\
Very low & $0 \%$ & $1 \%$ \\
\hline
\end{tabular}

Table 1 and Table 2 describe emotional intelligence scores obtained from respondents with an average of 79,928, standard deviations or standard deviations of 6.088 , this shows that the distribution of data spreads evenly means that the data points of each individual get closer to the average value while the minimum score is 66 , and the maximum score is 98 , the emotional intelligence of students in the high category is $22 \%$ and the medium category is $75 \%$.scores Self-efficacy obtained from respondents with an average of 88,015 and standard deviations or standard deviations of 11,849 , this shows that the distribution of data spreads evenly means that each data point is closer to the average value, while the minimum scores are 58 and a maximum score of 116, self-efficacy was students'14\% in the high category, and $55 \%$ in the moderate category. Student achievement test results obtained the highest value of 100.00 and the lowest value of 0.00 , the average obtained by 29.493 and the standard deviation of 18.907. The description of the data also explains that the average value of student learning achievement is not significant with the minimum classical completeness score for schools with an average of 7.00. This shows that the student achievement score data is far from the set value standard.

Testing the prerequisites of data analysis in this study are tests of normality, homogeneity, and linearity of partial regression lines between the independent variable and the dependent variable.

\section{Normality Test}

The calculation of normality test using SPSS 16.0 program, the analysis results are presented in the following Table 3.

Table 3. Normality Test

\begin{tabular}{lccc}
\hline & $\begin{array}{c}\text { Emotional } \\
\text { Intelligence }\end{array}$ & $\begin{array}{c}\text { Self- } \\
\text { Effycacy }\end{array}$ & $\begin{array}{c}\text { Achiev } \\
\text { ement }\end{array}$ \\
\hline $\begin{array}{l}\text { Kolmogorov- } \\
\begin{array}{l}\text { Smirnov Z } \\
\text { Asymp. Sig. } \\
\text { (2-tailed) }\end{array}\end{array}$ & 0,759 & 0,703 & 1,198 \\
\hline
\end{tabular}

Based on table 3, the value in the significance column Kolmogorov-Smirnov for all Variables (emotional intelligence, self-efficacy and learning achievement) is greater than 0.05. Thus, the data is normal distribution.

\section{Multicollinearity Test}

The calculation of multicollinearity test using the SPSS 16.0 program, the analysis result are presented in the following Table 4.

Table 4. Multicollinearity Test

\begin{tabular}{lcc}
\hline & \multicolumn{2}{c}{ Collinearity Statistics } \\
\cline { 2 - 3 } Model & Tolerance & VIF \\
\hline Emotional & 0,835 & 1,198 \\
Intelligence & 0,835 & 1,198 \\
Self-Efficacy &
\end{tabular}

Dependent Variable: Achievement

Based on the Table 4., the VIF value for emotional intelligence and self-efficacy i.e. 1,198 ; with the tolerance 0,835 . Thus, the both of variables has VIF value $<10$, so between independent variables non multicollinear.

\section{Heteroscedasticity test}

The calculation of heteroscedasticity test using SPSS 16.0 program, the analysis results are presented in the following Table 5.

Tabel 5. Heteroscedasticity Test

\begin{tabular}{lcc}
\hline Model & $\mathrm{t}$ & Sig. \\
\hline Emotional & 0,599 & 0,551 \\
Intelligence & 0,975 & 0,333 \\
Self Effycacy &
\end{tabular}




\section{JIPM (Jurnal Ilmiah Pendidikan Matematika), 8(1), September 2019- 42}

Muhamad Farhan, Edward Alfin

Based on Table 5., the both of variables has significance value more than 0,05 . The significance value of emotional intelligence variable i.e. $0,551>0,005$ and the significance value of self-efficacy variable i.e. $0,333>0,005$. Thus, there are nonheteroscedasticity.

\section{Linear Regresion Test}

The calculation of linear regresion test using SPSS 16.0 program, the analysis results are presented in the following Table 6 .

Table 6. Linear Regresion Test

\begin{tabular}{lccc}
\hline \multicolumn{1}{c}{ Model } & & F & Sig. \\
\hline Achievement $*$ & $\begin{array}{c}\text { Deviation } \\
\text { from }\end{array}$ & 1,180 & 0,311 \\
$\begin{array}{l}\text { Emotional } \\
\text { Intelligence }\end{array}$ & Linearity & & \\
$\begin{array}{l}\text { Achievement } * \text { Self } \\
\text { Effycacy }\end{array}$ & & 0,405 & 0,995 \\
\hline
\end{tabular}

In the Table 6., the value on the significance coloumn and row of deviation from linierity between of acvievement and emotional intelligence i.e. 0,311 and more than 0,05, the value between achievement and selfeffycacy i.e. 0,995 and more than 0,05. Thus, the line between emotional intelligence and self-efficacy is linear.

\section{Multiple Linear Regression Analysis}

The calculation of multiple linear regression using the SPSS 16.0 program, the analysis result are presented in the following Table 7.

Table 7. Variance Analysis

\begin{tabular}{lccccc}
\hline \multicolumn{1}{c}{ Model } & $\begin{array}{c}\text { Sum of } \\
\text { Squares }\end{array}$ & df & $\begin{array}{c}\text { Mean } \\
\text { Square }\end{array}$ & F & Sig. \\
\hline Regression & 762,026 & 2 & 381,013 & 1,068 & $0,350^{\mathrm{a}}$ \\
Residual & 23545,220 & 66 & 356,746 & & \\
Total & 24307,246 & 68 & & & \\
\hline
\end{tabular}

a. Predictors: (Constant), Effycacy, Emotional Intelligence

b. Dependent Variable: Achievement

Based on table 7 , the significance value in the $\mathrm{F}$ test of 0.350 is greater than 0.05 so it can be concluded that emotional intelligence and self-efficacy in this study simultaneously do not have a significant effect on learning achievement, meaning that with a significant significance value of emotional intelligence and self-efficacy has a relatively very weak effect on learning achievement. This is explained further in Table 8 of the Determination Analysis (R Square) as follows:

Table 8. Determination Analysis (R Square)

\begin{tabular}{lcccc}
\hline Model & $\mathrm{R}$ & $\begin{array}{c}\mathrm{R} \\
\text { Square }\end{array}$ & $\begin{array}{c}\text { Adjusted } \\
\mathrm{R} \text { Square }\end{array}$ & $\begin{array}{c}\text { Std. Error } \\
\text { of the } \\
\text { Estimate }\end{array}$ \\
\hline 1 & $0,177^{\mathrm{a}}$ & 0,031 & 0,002 & 18,88771 \\
\hline a. Predictors: (Constant), Efficacy, Emotional
\end{tabular}

The results of the analysis in table 8 obtained the coefficient of determination $\mathrm{R}$ (R Square) obtained a figure of 0.031, which means that emotional intelligence and selfefficacy affect student achievement by $3.1 \%$ while $96.9 \%$ is influenced by other variables outside this regression model that not researched.

Table 9. Result of Multiple Regression Analysis

\begin{tabular}{lccc}
\hline & (Constant) & $\begin{array}{c}\text { Emotional } \\
\text { Intelligence }\end{array}$ & $\begin{array}{c}\text { Self- } \\
\text { Efficacy }\end{array}$ \\
\hline Unstandardized B & -8.364 & 0,247 & 0,206 \\
Standardized Beta & & 0,079 & 0,129 \\
$\mathrm{t}$ & -.273 & 0,599 & 0,975 \\
Sig. & 0,785 & 0,551 & 0,333 \\
\hline \multicolumn{2}{l}{ Dependent Variable: Achievement }
\end{tabular}

Based on table 9. it can be explained that: a constant value of $-8,364$ means that if $\mathrm{X} 1$ and $\mathrm{X} 2$ value is 0 , then the magnitude of $\mathrm{Y}$ value is $-8,364$. The regression coefficient for variable $\mathrm{X} 1$ is 0.247 , meaning that each increase in $\mathrm{X} 1$ by 1 unit will increase $\mathrm{Y}$ by 0.247 units, assuming the other independent variables have a fixed value. The regression coefficient for variable $\mathrm{X} 2$ is 0.206 , meaning that every increase of $\mathrm{X} 2$ by 1 unit will increase $\mathrm{Y}$ by 0.206 units, assuming the other independent variables are of constant value.

Thus, table 9 reinforces the results in table 7 which shows that emotional intelligence and 
self efficacy do not have a significant effect on learning achievement.

\section{Discussion}

Based on the results of data analysis shows that the hypothesis in this study was rejected. The results of this study differ from the results of research conducted by previous researchers namely Ardyanti \& Harini (2015); Febrianti \& Rachmawati (2018); Safaria, (2013) and research by Salami \& Ogundokun (2009). However, the results of this study are supported by other studies conducted by Ngu, Hanafi, Taslikhan, \& Raman (2016) who examined the influence of emotional intelligence on learning achievement. In the final results of his study mentioned that there is no significant effect between emotional intelligence with academic achievement. Another study by Wong, Law, $\&$ Wong (2002) states that self-efficacy does not affect mathematics learning achievement, which means it is influenced by other factors not examined. Also supported by research results by Mohzan, Hassan, \& Halil (2013) which states that students have a high level of emotional intelligence, but no significant relationship was found between emotional intelligence and academic achievement.

Based on table 1 and table 2, the average learning achievement of Ar-Rahman Integrated Islamic Junior High School students in South Jakarta under the KKM is 29.49 , with the category of emotional intelligence students can be said to be moderate, high category students is $22 \%$, and medium category is $75 \%$ This does not have a significant effect on student achievement. Based on the analysis of Table 9, the significance value of emotional intelligence of 0.551 indicates a significance value greater than 0.05 . Thus the low mathematics learning achievement of SMP Islam Terpadu Ar-Rahman eighth grade students is influenced by other factors that are not the focus of this study.

Based on observations during conducting research and information obtained from mathematics teachers, the insignificant relationship between emotional intelligence with the learning achievement of SMP Islam Terpadu Ar-Rahman students can be explained by the following factors: a) Students interact more with the outside environment compared to interactions that occur in the family environment, due to the habits of students when returning from school do not immediately go home but do other activities outside such as selling and others, b) Student association is not well controlled by the family environment in this case parents, and c) Student attention to the rules that apply at school are not optimal, so the norms that apply at school are often ignored by students.

These three factors have a very significant influence on the development of SMP Islam Terpadu Ar-Rahman students' learning achievement, and these factors cannot be fully controlled in this study. The family becomes the first madrasa of a student to gain knowledge; the quality of a wellguarded family environment will produce a good quality of generation (students).

The level of emotional intelligence is indeed needed to achieve success, but in a small number of people, a high level of emotional intelligence is not always needed fully in helping to improve academic achievement. Ngu et al. (2016) say that emotional intelligence is not a major factor influencing student academic achievement. This happened to students of SMP Islam Terpadu Ar-Rahman South of Jakarta with emotional intelligence that can be said to be moderate apparently did not contribute significantly to student learning achievement. 
Likewise, self-efficacy students' did not have a significant effect on learning achievement when viewed from the self-efficacy of the high category students $14 \%$, and the moderate category $55 \%$ could be said to be moderate. On the other hand, based on the analysis of Table 9, the significance value of self-efficacy of 0.333 indicates a significance value greater than 0.05. Thus, the self-efficacy of ArRahman Integrated Islamic Middle School students who were classified as a medium did not have a significant influence on student achievement. The low mathematics learning achievement of SMP Islam Terpadu ArRahman students is influenced by other factors that are not the focus of this study.

The results mentioned above are similar to those delivered by Wong et al. (2002)that there is not always an effect between self-efficacy and expectations of results, even students who have high selfefficacy to learn, might think that they will get a score low if they think that the teacher does not like them, so the role of the teacher and the teacher's learning methods can also affect students' mathematics learning achievement.

Based on the observations of researchers during the research process, the insignificant relationship between self-efficacy and learning achievement can be explained by factors that influence self-confidence in students of Ar-Rahman Integrated Islamic Middle School can be explained by the following factors: a) Students tend to feel failed to solve a problem; individuals who previously failed in solving problems will feel unable to solve the problems faced so as to reduce their confidence to face the next task, b) the psychological condition of students who are often not well controlled, in the form of excessive fear and anxiety about failure in a task. This failure will make individuals feel unable and unsure to face the next task, and c). Students often go in and out of class when the learning process takes place.

\section{CONCLUSION}

The results of the study can be concluded that: There is no significant effect jointly between emotional intelligence and self-efficacy on learning achievement. This is indicated by the significant value in the $\mathrm{F}$ test of 0.350 greater than 0.05 . Emotional intelligence and self-efficacy, which are relatively moderate, do not have a significant influence on the improvement of learning achievement of SMP Islam Terpadu ArRahman students. This research can be used as a reference for other researchers so that research related to emotional intelligence and self-efficacy towards student learning achievement contributes more broadly to the progress of the world of education. In addition, it is expected that in subsequent studies research subjects can be further expanded so that research results can be more representative.

The implication of this study is that students who have high emotional intelligence and self-efficacy do not have a significant impact on improving learning achievement. Emotional intelligence and self-efficacy are not the main factors that influence student academic achievement. There are other internal and external factors that affect the learning achievement of SMP Islam Terpadu Ar-Rahman students. High levels of emotional intelligence and selfefficacy are not always needed to help improve student academic achievement. 


\section{REFERENCES}

Ardyanti, S. I., \& Harini, E. (2015). Hubungan Antara Adversity Quotient, Self Efficacy dan Kebiasaan Belajar dengan Prestasi Belajar Matematika Siswa Kelas X Kecantikan SMK. UNION: Jurnal Pendidikan Matematika, 3(1), 296-297.

Bagaka's, J. G. (2011). The role of teacher characteristics and practices on upper secondary school students' mathematics self-efficacy in Nyanza province of Kenya: A multilevel analysis. International Journal of Science and Mathematics Education, 9(4), 817-842. https:// doi.org/10.1007/s10763-010-9226-3

Bursal, M. (2010). Turkish Preservice Elementary Teachers' Self-Efficacy Beliefs Regarding Mathematics and Science Teaching. International Journal of Science and Mathematics Education, 8(4), 649-666. https://doi.org/10.1007/ s10763-009-9179-6

Daud, F. (2012). Pengaruh Kecerdasan Emosional (EQ) Dan Motivasi Belajar Terhadap Hasil Belajar Biologi Siswa SMA 3 Negeri Kota Palopo. Jurnal Pendidikan Dan Pembelajaran Universitas Negeri Malang, 19(2), 243-255.

Febrianti, L., \& Rachmawati, L. (2018). Pengaruh Kecerdasan Emosional dan Disiplin Belajar terhadap Hasil Belajar Siswa di SMA Negeri 3 Nganjuk. Jurnal Pendidikan Ekonomi (JUPE), 6(2), 69-75.

Goleman, D. (2015). Emotional Intelligence (Kecerdasan Emosional). Jakarta: PT Gramedia Pustaka Utama.

Hamdi, S., \& Abadi, A. M. (2014). Pengaruh Motivasi, Self-Efficacy dan Latar Belakang Pendidikan terhadap Prestasi Matematika Mahasiswa PGSD STKIP$\mathrm{H}$ dan PGMI IAJH. Jurnal Riset Pendidikan Matematika, 55(2), 77-87.
Hendriana, H., Rohaeti, E., E., \& Sumarmo, U. (2017). Hard Skills dan Soft Skills Matematika Siswa. Bandung: PT Refika Aditama.

Huang, X., Zhang, J., \& Hudson, L. (2018). Impact of math self-efficacy, math anxiety, and growth mindset on math and science career interest for middle school students: the gender moderating effect. European Journal of Psychology of Education, 621-640. https://doi.org/10.1007/s10212-0180403-z

Lee, C. W., Walkowiak, T. A., \& Nietfeld, J. L. (2017). Characterization of mathematics instructional practises for prospective elementary teachers with varying levels of self-efficacy in classroom management and mathematics teaching. Mathematics Education Research Journal, 29(1), 4572. https://doi.org/10.1007/s13394-0160185-z

Louis, R. A., \& Mistele, J. M. (2012). the Differences in Scores and Self-Efficacy By Student Gender in Mathematics and Science. International Journal of Science and Mathematics Education, 10(5), 1163-1190. https://doi.org/10. 1007/s10763-011-9325-9

Maharani, S., Nusantara, T., Rahman, A., \& Qohar, A. (2019). Analyticity and Systematicity Students of Mathematics Education on Solving Non-routine Problems. Mathematics and Statistics, 7(2), 50-55. https://doi.org/10.13189/ ms.2019.070204

Maltby, J., Day, L., \& Macaskill, A. (2010). Personality, individual differences and intelligence. London: Pearson.

Mohzan, M. A. M., Hassan, N., \& Halil, N. A. (2013). The Influence of Emotional Intelligence on Academic Achievement. 
Procedia - Social and Behavioral Sciences, 90(InCULT 2012), 303-312. https://doi.org/10.1016/j.sbspro.2013.07.095

Ngu, L., Hanafi, Z., Taslikhan, M., \& Raman, A. (2016). Influence of emotional intelligence on students' academic achievements. International Journal of Humanities and Social Science Research, 2(3), 41-46.

Nurdiansyah, E. (2016). Pengaruh Kecerdasan Spiritual, Kecerdasan Emosional, Dampak Negatif Jejaring Sosial Dan Kemampuan Berpikir Divergen Terhadap Hasil Belajar Matematika Siswa. Journal of Educational Science and Technology (EST), 2(3), 171-184. https://doi.org/10. 26858/est.v2i3.3216

Safaria, A. A. T. (2013). Effects of SelfEfficacy on Students' Academic Performance. Journal of Educational, Health and Community Psychology, 2(1), 22-29. https://doi.org/10.12928 jehcp.v2i1.3740
Salami, S. ., \& Ogundokun, M. . (2009). Emotional intelligence and academic self-efficacy as predictors of academic performance among senior secondary school students in Oyo state, Nigeria. Perspectives in Education, 25(3), 175185.

Slameto, S. (2015). Belajar dan Faktor-Faktor yang Mempengaruhinya. Jakarta: Rineka Cipta.

Thaib, E. N. (2013). Hubungan Antara Prestasi Belajar dengan Kecerdasan Emosional. Jurnal Ilmiah Didaktika, 13(2), 384 399. Retrieved from http;//.id/index.php/ didaktika/article/view/485

Wong, C., Law, K. S., \& Wong, P. (2002). Development and validation of a nonself-report emotional intelligence measure in Hong Kong. Asian Academy of Management Conference, 535-559. https://doi.org/10.1023/B:APJM.000004 8717.31261.d0 